\title{
The Impact of Culture on Well-Being: Evidence from a Natural Experiment
}

\author{
Gábor Hajdu \\ Institute for Sociology, Centre for Social Science, Hungarian Academy of Sciences, Hungary; \\ and MTA-ELTE Peripato Comparative Social Dynamics Research Group, Hungary \\ E-mail: hajdu.gabor@tk.mta.hu
}

Tamás Hajdu

Institute of Economics, Centre for Economic and Regional Studies, Hungarian Academy of Sciences, Hungary

E-mail: hajdu.tamas@krtk.mta.hu

The final publication is available at Springer via http://dx.doi.org/10.1007/s10902-015-9633-9 


\section{The Impact of Culture on Well-Being: Evidence from a Natural Experiment}

\section{Introduction}

In recent decades, cross-country comparison has gained increasing significance in social sciences as international migration has increased and borders have opened up, thus separating people less. Consequently, the analysis of the cultural determinants of different economic and social outcomes has been receiving more attention.

The vast majority of papers on well-being deal with the extrinsic socio-demographic, economic and political causes and correlates. A smaller but growing literature examines how culture contributes to individuals' subjective well-being (Diener 2009; Diener and Suh 2000; Knoop and Delle Fave 2013; Oishi 2010; Suh and Koo 2008). Initially, empirical research concentrated on the effect of language and on the cultural concept of subjective well-being (Oishi 2010; Veenhoven 1993, 1996). Inglehart and Klingemann (2000) found that, although well-being is largely determined by genes (Lykken and Tellegen 1996), beliefs and values have a sizeable influence on it: the protestant heritage has a positive impact on the average satisfaction of countries. Several studies show that individualism/collectivism is strongly related to satisfaction: people living in individualist countries tend to be more satisfied than people in collectivist countries because they can choose their personal goals and have more personal freedom (Diener et al. 1995; Suh and Oishi 2002). Helliwell and Putnam (2004), and Helliwell and Wang (2011) show that interpersonal and institutional trust both on the individual and on the national level has a positive impact on well-being. In an experiment, Kasser and Ahuvia (2002) found that students with strong materialistic values tend to be less happy, whereas Kasser and Ryan (1993) have revealed that materialistic values are typically associated with lower well-being and mental health.

These papers face two methodological problems: the direction of causality and omitted variables. One of the main challenges in analyzing the impact of culture is the problem of reverse and two-way causality: the impact may work both from culture to well-being and from well-being to culture. Another difficulty is that culture and environment are correlated: it is not easy to distinguish the effect of culture from the effect of a country's economic, institutional and social characteristics. When using cross-sectional data, we cannot control for every relevant variable: we cannot decide whether cultural variables or omitted environmental 
characteristics explain the differences observed. For example, Inglehart and Klingeman (2000) show that people living in more democratic countries are likely to be more satisfied, but they note that this is due at least partially to a higher level of economic development. When using panel or time series data, although we can control for time-invariant factors, we encounter the problem that values are fairly stable over time, hence it is difficult to observe enough variation in these variables and study the effect of value-changes.

The aim of this paper is to examine the effect of culture on life satisfaction (the cognitive aspect of subjective well-being) using international migration as a natural experiment. Our main research question is whether culture is an important determinant of life satisfaction Here culture is defined in a narrow term: as a set of values, beliefs, attitudes and norms transmitted between generations (Guiso, Sapienza and Zingales 2006) or following Fernández (2011: 484), differences in culture are defined "as systematic variation in beliefs and preferences across time, space, or social groups". That is, the notion of culture describes those intrinsic factors, such as values, beliefs and mental attitudes that form people's "cultural heritage".

The empirical method we use in this paper is called "the epidemiological approach". It allows us to isolate cultural effects from environmental effects and to avoid the issue of reverse causality (Fernández, 2011). The main innovation of this method is that it uses data on immigrants to study the role of culture in the variation of different outcomes. Using a sample of immigrants and taking into account the "portability" of norms, beliefs and mental attitudes, i.e. "portability" of culture (Fernández and Fogli 2009) relative to other economic, social, and institutional factors is a useful solution to the above mentioned problems of the previous literature. International migration provides a natural experiment because immigrants come from diverse cultures but in their host country share they the same environment (economy, institutions, political regime and law) with other immigrants.

Since in a particular country immigrants with the same economic and socio-demographic characteristics differ only in their cultural backgrounds, differences in their life satisfaction can be interpreted as the effect of cultural heritage. More specifically, our empirical research question is the following: in a particular residence country are immigrants from countries with high levels of life satisfaction more satisfied than immigrants from countries with low levels of life satisfaction? In other words, we examine if average life satisfaction in the birth country has a positive impact on immigrants' life satisfaction. Although average life satisfaction in the birth country depends on environmental (e.g. economy, institutions, political and social features) and cultural factors as well, it is reasonable to assume that environmental variables 
of the birth country do not have a sizable impact on immigrants' satisfaction in the residence country. Thus, a positive association between immigrants' life satisfaction and the average life satisfaction in the birth country could be interpreted as the effect of the cultural component, i.e. as evidence for the causal effect of culture (persistent values, beliefs and norms) on individual subjective well-being. ${ }^{1}$

Our analysis is related to the growing literature that uses this method to study the effect of culture on various economic and societal outcomes. The first papers were published in the 90s and in recent years samples of immigrants have been increasingly used to identify the effect of culture. Algan and Cahuc (2010) and Dinesen (2013) showed that immigrants' generalized trust is determined by the culture of their country of origin (in terms of the level of trust of this country). Luttmer and Singhal (2011) related immigrants' preference for redistribution to the average preference in their birth countries and concluded that preferences for redistribution have cultural determinants. Fernández and Fogli (2006, 2009) examined fertility and labor force participation of women in the United States and provided evidence that total fertility rates and female labor force participation in the woman's country of ancestry are determinants of women's fertility and labor force participation. Blau, Kahn and Papps (2011) demonstrated that labor supply of first-generation immigrant women in the United States is positively associated with the labor supply of the source country, while Blau, Kahn, Liu and Papps (2013) showed that fertility, education and labor supply of second-generation immigrant women are positively affected by these variables of the source country. Both papers suggested that these findings can be interpreted as the impact of culture, or more specifically as the impact of gender roles' transmission. Using the epidemiological approach Alesina and Giuliano (2010) found that among second-generation immigrants in the United States, women and young adults from countries with strong family ties participate less in the labor market, and strong family ties are also associated with less geographical mobility. Carroll, Rhee and Rhee (1994), comparing saving behavior of immigrants with different cultural backgrounds in Canada, found no evidence that cultural factors influence saving behavior.

In the context of culture and well-being there are only few papers that relate immigrants' satisfaction to satisfaction in country of origin. Veenhoven (1994) reports studies that compared immigrants' satisfaction in Australia and Germany to their birth countries and

\footnotetext{
${ }^{1}$ We have to emphasize that although we analyze the determinants of immigrants' life satisfaction, we use this special sample purely for a methodological reason: in this way we are able to isolate the effect of culture from external factors (institutions. policies, markets, etc.).
} 
yielded contradictory results. Rice and Steele (2004) analysed a sample of Americans from General Social Survey data. They found that the average well-being score in the country of origin $^{2}$ correlates with the well-being of Americans. In a sample of seven European countries, Senik (2014) finds that living in a given country affects immigrants' and natives' satisfaction differently. Senik argues that the unhappiness of the French and the heterogeneity of happiness in cross-country comparison can be explained by mental attitudes.

The main novelty of our paper is that it analyses the impact of culture on well-being, applying a well-founded methodology that is able to avoid the problem of reverse causality using data from several residence and birth countries. Using data from 34 countries and five waves of the European Social Survey (2002-2010) and building on Luttmer and Singhal's (2011) exercise, this paper demonstrates that average life satisfaction in the birth country has a positive and significant effect on individuals' life satisfaction among European immigrants. This means that immigrants who come from countries with high levels of life satisfaction tend to be more satisfied than immigrants who migrate from countries with low levels of life satisfaction, even if they are living in the same environment (in the same country) and have same personal characteristics. Moreover, we find the same effect among immigrants who migrated to Europe and were born in one of the 96 participating countries of the World Values Survey. Concerns that our result might be driven by selective migration are primarily relaxed by two results: (i) the effect is robust to the choice of the sample, of the control variables, and of the estimation method, and (ii) we observe the same effect for second-generation immigrants as well. We interpret our results as evidence for the effect of culture, since any observed differences among the immigrants is their cultural background (their birth countries).

Our interpretation is supported by the results that the impact of average satisfaction in the birth country appears stronger among immigrants who are more attached to their birth country's culture. We find that average life satisfaction in the birth country affects immigrants' satisfaction more strongly if they have lived less in the residence country, if they were adults at the time of their migration and therefore had less influential peer groups and school socialization effects in the residence country, if they are non-citizens of the residence country, if they speak a non-official language on a regular basis at home, and if the residence

\footnotetext{
${ }^{2}$ The country of origin was identified with the following question: „From what countries or part of the world did your ancestors come?"
} 
country is more permissive towards retaining the birth country's culture. Summing up, our results suggest that, indeed, culture does have a visible effect on subjective well-being. ${ }^{3}$

Our paper is structured as follows. The next section describes the data and explains our methodology. Section 3 provides some illustrative results about the main findings and shows the estimation of the OLS model. In Section 3.1 we test the robustness of the estimations using alternative estimation techniques and changing the control variables. In Section 3.2 we test whether the effect of average satisfaction in the birth country is indeed stronger for immigrants who are more attached to their birth country's culture. In Section 3.3 we run models for second-generation immigrants to test whether the effect lasts across generations. Section 4 concludes.

\section{Data and methodology}

As discussed in the Introduction, the empirical method we use is the epidemiological approach that allows us to isolate cultural effects from environmental effects (Fernández, 2011). Therefore, we analyze a sample of immigrants with diverse cultural backgrounds who share the same environment in their host country. It means that, controlling for their personal characteristics, any observed difference in immigrants' satisfaction can be accounted for their culture.

We use data from five rounds of the European Social Survey (ESS). ESS is a repeated crosssectional survey from every other year (2002-2003, 2004-2005, 2006-2007, 2008-2009, 20102011), which contains data for 34 European countries for at least one round, and for 16 countries for all five rounds. Our sample consists of immigrants: respondents who were born outside the country. The analysis is restricted to respondents born in another ESS country. Respondents with missing life satisfaction, age or gender variables are dropped. Respondents who report being born outside the residence country but their birth country variable is missing or the birth country variable and "born in country" variable are inconsistent (total 161 observations) are also dropped. The final sample size is 12,085 . $^{4}$

\footnotetext{
${ }^{3}$ Arguably, genuine cultural impact is captured, caused by differences in values, attitudes and beliefs, and the results are free from cultural bias (different response styles or social desirability), or at least are not primarily driven by it (Hui and Triandis 1989; OECD 2013; van de Vijver and Poortinga 1997). Although it is hard or impossible to distinguish between cultural impact and cultural bias, the risk of cultural bias can be managed by careful survey design and translation process (OECD 2013). It has to be emphasized that the ESS tries to ensure optimal comparability and the equivalence of the different language versions of the questionnaires.

${ }^{4}$ Demographic characteristics of the sample are given in Table A1 of the Appendix.
} 
As there are 34 participating countries in the five rounds of ESS, there are potentially 34 birth countries and 34 residence countries in the data. There is sufficient heterogeneity in this sample: there are immigrants in 566 cells out of the possible 1122 cells of this migration matrix, which means 50.45 percent of the potential migration ways are included in the data. Table 1 reports immigrant flow across the 34 countries. The most representative groups come from Russia (2571 observations), Germany (1192 observations) and the United Kingdom (843 observations), whereas Switzerland, Estonia, and Israel are the most popular destination countries (1277, 1115, 1089 observations respectively). 
Hajdu, Gábor - Hajdu, Tamás (2015): The Impact of Culture on Well-Being: Evidence from a Natural Experiment The final publication is available at Springer via http://dx.doi.org/10.1007/s10902-015-9633-9

Table 1: Immigrants by birth country and destination country

\begin{tabular}{|c|c|c|c|c|}
\hline & \multicolumn{2}{|c|}{ Immigrants by birth country } & \multicolumn{2}{|c|}{ Immigrants by destination country } \\
\hline & $\begin{array}{l}\text { Number of } \\
\text { immigrants } \\
\text { from birth } \\
\text { country }\end{array}$ & $\begin{array}{c}\text { Number of } \\
\text { destination } \\
\text { countries }\end{array}$ & $\begin{array}{c}\text { Number of } \\
\text { immigrants in } \\
\text { destination } \\
\text { country }\end{array}$ & $\begin{array}{l}\text { Number of birth } \\
\text { countries }\end{array}$ \\
\hline Austria & 173 & 18 & 383 & 25 \\
\hline Belgium & 216 & 19 & 498 & 23 \\
\hline Bulgaria & 153 & 22 & 44 & 6 \\
\hline Croatia & 275 & 12 & 43 & 9 \\
\hline Cyprus & 24 & 7 & 145 & 14 \\
\hline Czech Republic & 245 & 19 & 206 & 12 \\
\hline Denmark & 118 & 13 & 199 & 26 \\
\hline Estonia & 56 & 8 & 1115 & 11 \\
\hline Finland & 250 & 12 & 190 & 20 \\
\hline France & 666 & 24 & 285 & 25 \\
\hline Germany & 1192 & 30 & 803 & 31 \\
\hline Greece & 116 & 17 & 292 & 20 \\
\hline Hungary & 160 & 22 & 123 & 10 \\
\hline Iceland & 25 & 5 & 9 & 3 \\
\hline Ireland & 106 & 10 & 906 & 26 \\
\hline Israel & 17 & 10 & 1089 & 25 \\
\hline Italy & 600 & 21 & 37 & 14 \\
\hline Latvia & 83 & 13 & 368 & 6 \\
\hline Lithuania & 122 & 14 & 54 & 6 \\
\hline Luxemburg & 12 & 6 & 775 & 22 \\
\hline Netherlands & 239 & 18 & 301 & 26 \\
\hline Norway & 78 & 11 & 325 & 23 \\
\hline Poland & 721 & 25 & 71 & 10 \\
\hline Portugal & 495 & 11 & 120 & 13 \\
\hline Romania & 555 & 26 & 7 & 4 \\
\hline Russia & 2571 & 28 & 154 & 9 \\
\hline Slovakia & 206 & 19 & 169 & 8 \\
\hline Slovenia & 49 & 11 & 237 & 12 \\
\hline Spain & 189 & 17 & 252 & 20 \\
\hline Sweden & 209 & 16 & 558 & 30 \\
\hline Switzerland & 78 & 17 & 1277 & 30 \\
\hline Turkey & 556 & 15 & 35 & 5 \\
\hline United Kingdom & 843 & 21 & 343 & 29 \\
\hline Ukraine & 687 & 29 & 672 & 13 \\
\hline
\end{tabular}

We estimate the impact of average life satisfaction in the birth country on life satisfaction, using the following OLS regression: 
$S_{i}=\beta_{0}+\beta_{1} \bar{S}_{k}+\beta_{2} X_{i}+\delta_{r}+\lambda_{t}+\varepsilon_{i}$

where $S_{i}$ is the satisfaction of immigrant $i, \bar{S}_{k}$ denotes the average satisfaction in the birth country $k$ of immigrant $i, X_{i}$ is the vector of personal characteristics ${ }^{5}$ of immigrant $i$. We also include residence country dummies $\left(\delta_{r}\right)$ to control for unobserved time-invariant country characteristics, and wave dummies $\left(\lambda_{t}\right)$ that accounts for time trends that are common to all countries. Finally, the equation includes the usual error term $\left(\varepsilon_{i}\right)$. Standard errors are clustered at the birth country level.

The measure of subjective well-being is the cognitive evaluation of life quality (Diener et al. 1999 ) with a single item question on an 11-point scale (0 - extremely dissatisfied, 10 extremely satisfied): "All things considered, how satisfied are you with your life as a whole nowadays?" This variable is a valid and reliable measure of life satisfaction, and is used widely in the literature (Diener et al. 2013; Frey 2008; Frey and Stutzer 2002; OECD 2013). 6 Using this variable, we attempt to capture countries' "permanent" satisfaction, which is not sensitive to other temporary shocks. ${ }^{7} \mathrm{We}$ do this as follows: First, we calculate the mean satisfaction of the native respondents in all ESS rounds (weighting by design weight provided in the dataset), then we take the average of the five rounds. We use this measure as the main independent variable: average life satisfaction in immigrant's birth country.

Since there are dummies for the residence countries in the model that capture the timeinvariant and unobservable country-specific effects, coefficient of $\bar{S}_{k}$ can be interpreted as follows: whether in a particular residence country immigrant A who comes from a birth country with a high satisfaction level is more satisfied than immigrant B who was born in a country with a low satisfaction level if they have the same personal characteristics. Since they live in the same country, they share the same external environment (economy, institutions, law, welfare policy, etc.), and since we can also capture the effect of relevant sociodemographic factors, the only difference between them is their cultural backgrounds. Thus, if $\beta_{1}$ is positive and significant, we can interpret it as evidence for the effect of cultural heritage

\footnotetext{
${ }^{5}$ We include variables that are standard control variables in the empirical literature (Dolan et al. 2008; Frey and Stutzer 2002): age, squared age, female respondent, education (measured by International Standard Classification of Education - ISCED), living with a partner, main activity, living in a city, activity limitation (hampered in daily activities by disability or any health problem), household's total net income in logarithmic form, relative income (ratio of household income to average income in the country), and household size.

${ }^{6}$ Although our main interest is in life satisfaction, we checked the results using an alternative measure of wellbeing as well. Happiness was measured on an 11-pont scale: "Taking all things together, how happy would you say you are?" Using this variable does not change the inference.

${ }^{7}$ On the effect of temporary shocks on well-being, see e.g. Deaton (2012) or Askitas and Zimmermann (2011).
} 
on life satisfaction. If life satisfaction were influenced solely by socio-demographic factors and the external environment, and cultural factors did not play a role, the average life satisfaction in the immigrant's birth country should not matter, i.e. $\beta_{1}$ would be insignificant. $^{8}$

Although we argue that a positive coefficient on the average satisfaction in the birth country provides evidence that culture does matter, there is a theoretical possibility that selective migration can spuriously generate this result. There is empirical evidence that immigrants are not a random sample of their birth country's population: dissatisfied people have greater intention to migrate (Otrachshenko \& Popova 2014), but spurious result would require immigrants from countries with high life satisfaction levels to be systematically different regarding an unobserved variable from immigrants from countries with low life satisfaction levels. In particular, the former immigrants should have higher life satisfaction driven by this unobserved variable. In this case, we would see that an immigrant from a country with a high satisfaction level is more satisfied than another immigrant from a country with a low satisfaction level even if they share the same external environment and observed sociodemographic characteristics; however, this difference would be not due to variation in cultural heritage. This is a strong assumption and it is unlikely that our results could be driven by such a selective migration, since we control for a rich set of socio-demographic variables that might have relevant impact on immigrants' life satisfaction. It is worth noting that selective migration could cause spurious results (a positive coefficient on satisfaction in the birth country without any real cultural effect) only in this case. ${ }^{9}$

\section{Results}

Figure 1 illustrates the basic relationship between the average life satisfaction in the birth country and immigrants' satisfaction. On the vertical axis we measure the deviation of immigrants' satisfaction from the mean satisfaction of the residence country. Each point depicts the average deviation for all immigrants from a birth country (country labels denote countries of birth). On the horizontal axis we plot average satisfaction in the birth countries.

\footnotetext{
${ }^{8}$ As mentioned above, average life satisfaction in the birth country depends on environmental and cultural factors, but we should not expect environment of the birth country to have a sizable effect on immigrants' satisfaction in the residence country. Therefore, the positive coefficient on average life satisfaction in the birth country can be interpreted as the effect of the cultural component.

${ }^{9}$ Moreover, Fernández (2011: 496) argues that "the epidemiological approach is biased towards finding that culture does not matter" since the effect of birth country culture is likely to diminish over time.
} 
The positive slope of the trend line means that the higher the life satisfaction in the birth country the more satisfied the immigrants are, i.e. birth country life satisfaction is positively associated with immigrants' satisfaction.

Figure 1: Immigrants' satisfaction by birth country

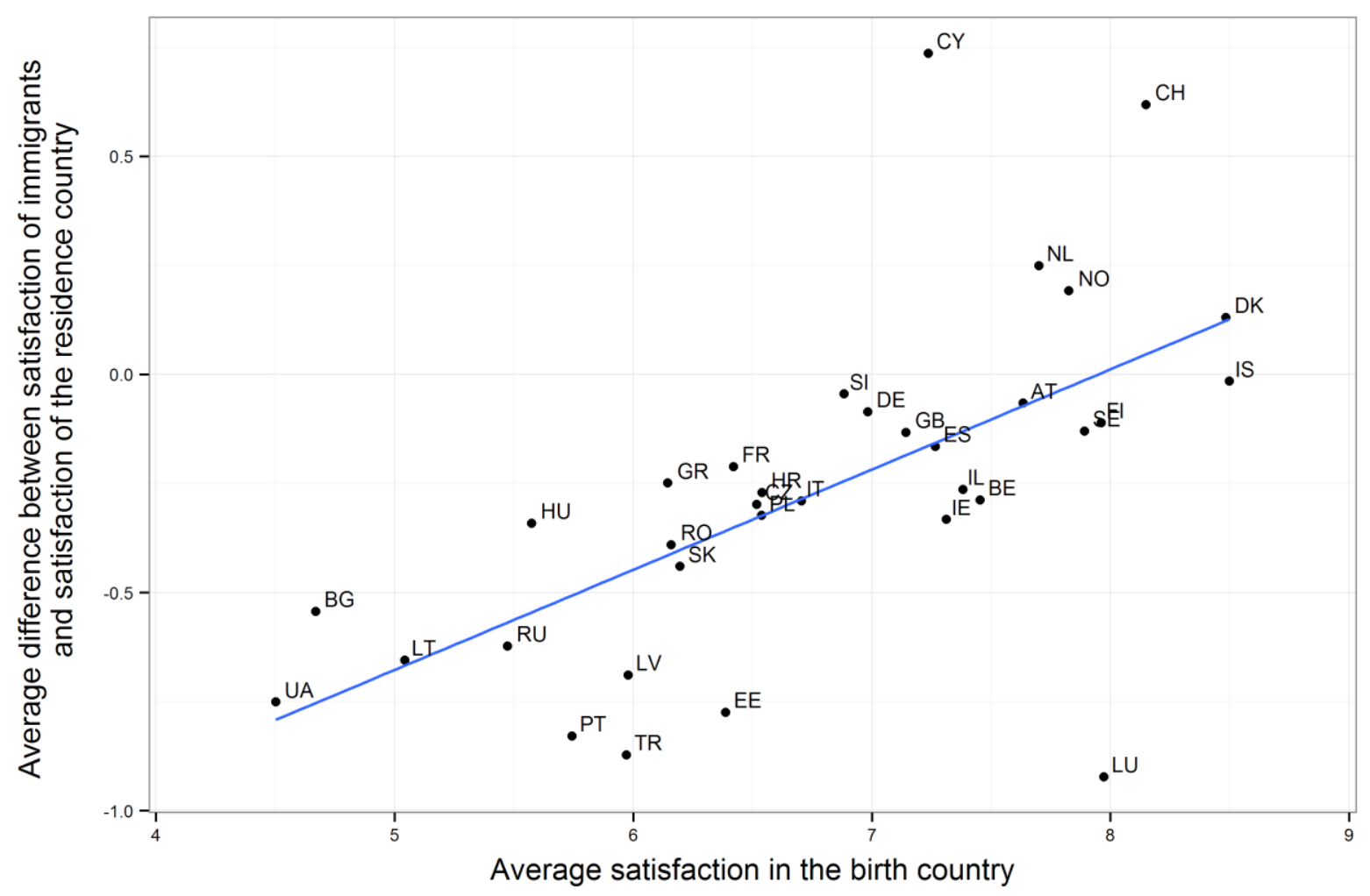

Note: Labels indicate birth countries: AT - Austria, BE - Belgium, BG - Bulgaria, CH - Switzerland, CY Cyprus, CZ - Czech Republic, DE - Germany, DK - Denmark, EE - Estonia, ES - Spain, FI - Finland, FR France, GB - United Kingdom, GR - Greece, HR - Croatia, HU - Hungary, IE - Ireland, IL - Israel, IS Iceland, IT - Italy, LT - Lithuania, LU - Luxemburg, LV - Latvia, NL - Netherlands, NO - Norway, PL Poland, PT - Portugal, RO - Romania, RU - Russia, SE - Sweden, SI - Slovenia, SK - Slovakia, TR - Turkey, UA - Ukraine

Figure 2 illustrates the same relationship for each residence country. The illustrations represent the average life satisfaction in the birth countries and the average satisfaction of immigrants born in the birth country. Each point indicates a birth country with at least five observations (individuals), and only those residence countries are represented where we have immigrants from at least five birth countries. In 17 of the 19 residence countries immigrants born in a country with a high satisfaction level are more satisfied than immigrants born in a country with a low satisfaction level. 
Figure 2: Immigrants' satisfaction by birth country in each residence country

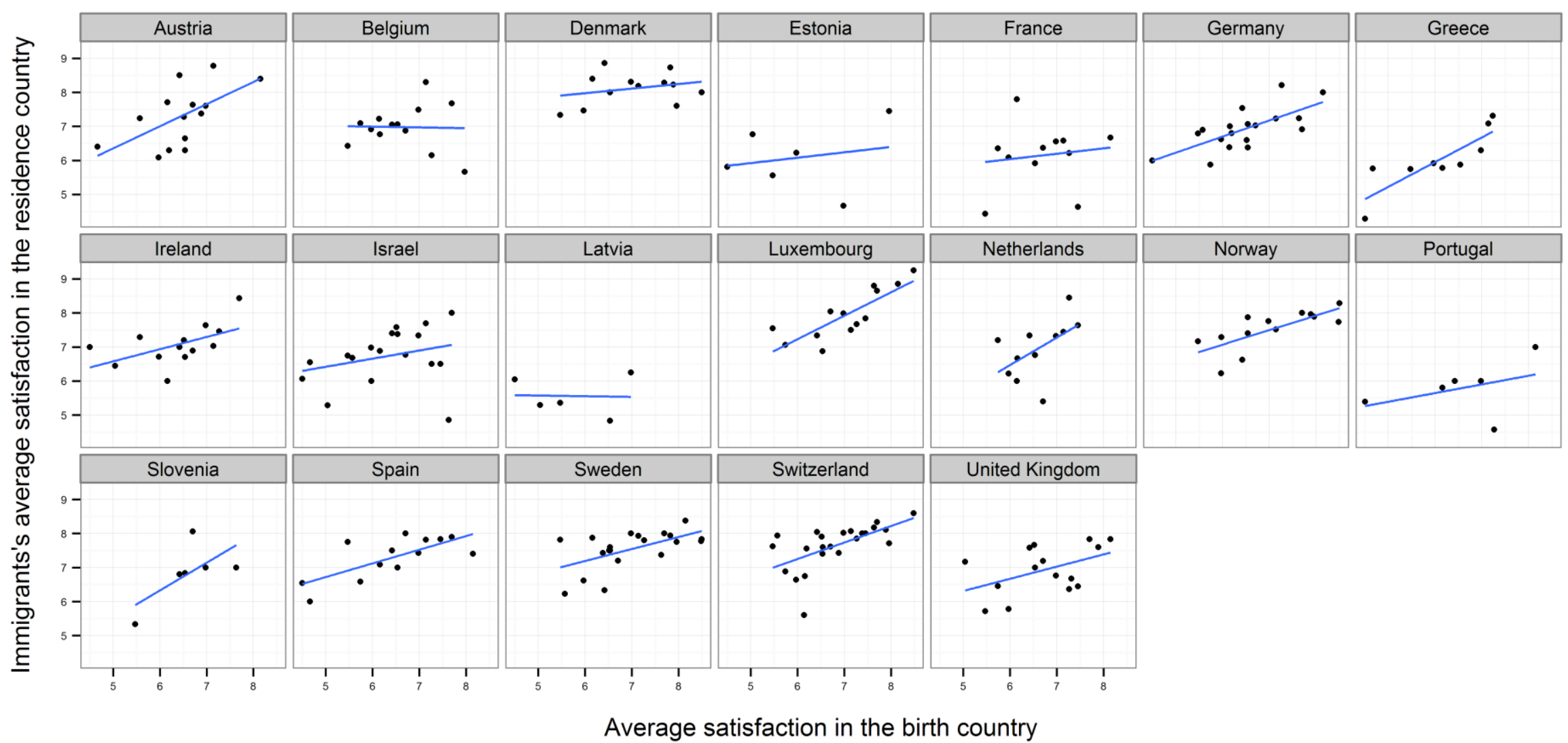

Note: The headers of the plots are labeled by residence countries. Every point represents immigrants' average satisfaction from a given birth country from where immigrants have come to the particular residence country. 
The relationships in Figure 1 and 2 might be explained by a composition effect: differences in satisfaction can be derived from differences in economic and socio-demographic characteristics of immigrants and natives from different countries. We run the OLS model to control for these variables and to rule out this possibility.

The results for the OLS model are shown in Table 2. Coefficients on variables of individual characteristics correspond with earlier findings (Dolan et al. 2008; Frey and Stutzer 2002). ${ }^{10}$ Satisfaction decreases with age, and it starts to increase around the age of 47 years. Individuals living with a partner report higher level of satisfaction than others. Students are more satisfied than people in paid work, and the unemployed are less satisfied than those in employment. The effect of the health proxy (activity limitation) is very strong. Coefficients on log household income and relative income are positive.

The coefficient on satisfaction in the individual's birth country is positive and significant. One unit increase in average satisfaction in the immigrant's birth country is associated with a 0.283 increase in the immigrant's satisfaction. In any given residence country, immigrants from countries with high satisfaction levels are ceteris paribus more satisfied than immigrants from countries with low satisfaction levels.

The effect of one standard deviation increase of average satisfaction in the birth country has a magnitude similar to 70 percent of the effect of being married or living with a partner, 25-33 percent of the effect of unemployment, and 140 percent of the effect of living in a city or town. Moreover, if we take for instance immigrants who live in the same residence country and have identical personal characteristics, we will observe a satisfaction gap of 1.13 points between an immigrant from the country with the lowest satisfaction level (Ukraine) and one from the country with the second highest satisfaction level (Denmark) and this difference can be attributed to cultural heritage. Since our model includes dummy variables for the residence country and the most important individual variables, we may assume that the different cultural background can explain the difference. ${ }^{11}$ This means that culture (transmitted values, beliefs

\footnotetext{
${ }^{10}$ Excluding mean satisfaction in the birth country from the model, results for immigrants and natives are very similar, thus we suppose that the effect of culture would be the same for natives - if we were able to capture it.

${ }^{11}$ Although omitted individual variables could be at least partially responsible for the observed effect of average satisfaction in the birth country if they differ systematically between immigrants from countries with high and low satisfaction levels, we show in the next section that the observed effect remains the same if we control for a richer set of individual characteristics. On the other hand, in line with the literature (Fernández and Fogli 2009; Luttmer and Singhal 2011), we assume that the economic, institutional and social environment of the birth country does not have any sizeable impact on the immigrants' life satisfaction in their new country. In the next section, we also show that in a model controlling for important characteristics of the birth country the effect of satisfaction in the birth country does not change.
} 
and norms) is not only statistically significant but is also a meaningful determinant of wellbeing, and its magnitude is comparable to those of social and economic factors.

Table 2: Determinants of subjective well-being, OLS

\begin{tabular}{lcc}
\hline & $\mathrm{B}$ & Robust SE \\
\hline Satisfaction in the birth country & $0.283^{* * *}$ & $(0.030)$ \\
Age & $-0.069^{* * *}$ & $(0.007)$ \\
Age squared & $0.001^{* * *}$ & $(0.000)$ \\
Female & $0.063^{*}$ & $(0.036)$ \\
Education: ISCED 5-6, tertiary education completed & $0.178^{* * *}$ & $(0.039)$ \\
Married or living with a partner & $0.360^{* * *}$ & $(0.050)$ \\
Main activity (ref. cat.: Paid work) & & \\
Education & $0.216^{* *}$ & $(0.095)$ \\
Unemployed, looking for a job & $-1.045^{* * *}$ & $(0.091)$ \\
Unemployed, not looking for a job & $-0.770^{* * *}$ & $(0.180)$ \\
Retired & 0.012 & $(0.051)$ \\
Housework & 0.045 & $(0.082)$ \\
Other & $-0.452^{* * *}$ & $(0.116)$ \\
City/town & $-0.182^{* * *}$ & $(0.054)$ \\
Activity limitation & $-0.791^{* * *}$ & $(0.046)$ \\
LN(household's total net income, all sources) & $0.226^{* * *}$ & $(0.049)$ \\
Relative income & $0.105^{* *}$ & $(0.043)$ \\
Household size & -0.009 & $(0.021)$ \\
Wave dummies & Yes & \\
Residence country dummies & Yes & \\
\hline Adjusted R ${ }^{2}$ & 0.237 & \\
N & 12085 & \\
\hline
\end{tabular}

Dependent variable: Life satisfaction

Robust standard errors adjusted for clustering by birth country are in parentheses. Dummies are included for missing regressors.

$* \mathrm{p}<0.10, * * \mathrm{p}<0.05, * * * \mathrm{p}<0.01$

\subsection{Robustness}

Next, we test the robustness of the estimations. On the one hand, we use an alternative technique to create the average satisfaction of the countries of birth, on the other hand, we change control variables. First, we calculate the satisfaction in the birth country by running an OLS regression model for native respondents with individual control variables, wave dummies, and country dummies as in Table 2, and then we take the coefficients on country dummies as proxy for the satisfaction in the birth country. This variable represents the 
satisfaction when holding individual characteristics constant, and reflects the effect of culture and institutions, as well as omitted individual variables. Row 1 in Table 3 shows the result. The coefficient on the satisfaction in the birth country is similar to the main model $(0.325)$, thus it is not driven by the different socio-demographic characteristics of the birth countries.

In row 2 we turn to considering an alternative dataset. In this model, mean life satisfaction in the birth country is calculated from the World Values Survey data ${ }^{12}$ for far more countries. Thus in this model we have 34 residence countries from the ESS dataset and 96 birth countries from the WVS dataset. The result is robust to enlarging the number of birth countries with non-European countries: the estimated coefficient is significant and has a magnitude that is similar to the baseline model (0.249).

In rows 3-5 of Table 3, we test the robustness of the estimations to the choice of the control variables. Row 3 presents the result with additional individual control variables: religiousness, sociability (how often the respondents meet friends, relatives or colleagues), having someone to discuss intimate and personal matters with, dummy for citizenship, and the length of time the respondent has lived in the residence country. The estimated effect is robust to controlling for more comprehensive individual characteristics; this specification yields similar results to the baseline model.

We next add controls for relevant country-level variables that the literature considers significant determinants of well-being: GDP in logarithmic form (Deaton 2008; Diener et al. 1995; Stevenson and Wolfers 2013), the Gini-coefficient (Alesina et al. 2004; Grosfeld and Senik 2010; Hajdu and Hajdu 2014), inflation rate, and unemployment rate (Di Tella et al. 2003; Wolfers 2003). Rows 4 and 5 present the results with additional country-level economic and social variables of residence country and birth country respectively. When controlling for these economic and social characteristics of the residence country, the size of the estimated coefficient on satisfaction in the birth country does not change (row 4). When including the economic and social characteristics of the birth country (row 5), the coefficient on average satisfaction slightly decreases (0.216) but remains significant at the $1 \%$ level.

The estimated effect is also robust to the sample choice and the estimation method choice: for instance excluding five birth countries with the lowest or the highest satisfaction, running the

\footnotetext{
${ }^{12}$ We use the integrated World Values Survey and European Values Survey data. We calculate the average life satisfaction in an immigrant's birth country by computing the weighted mean satisfaction of all respondents in all six rounds of WVS and EVS (five rounds of WVS: 1981-1984, 1989-1993, 1994-1999, 1999-2004, 20052007, four rounds of EVS: 1981-1984, 1990-1993, 1999-2001, 2008-2010), and then taking the average of the six mean satisfactions.
} 
model without post-communist birth countries, running ordered logit or ordered probit models. For the full list of specifications and the results, see Table A2 in the Appendix.

Table 3: Effects of satisfaction in the birth country on subjective well-being, OLS

\begin{tabular}{llccc}
\hline & $\begin{array}{c}\text { Coefficient on } \\
\text { satisfaction in } \\
\text { the birth country }\end{array}$ & $\begin{array}{c}\text { Robust } \\
\text { SE }\end{array}$ & $\begin{array}{c}\text { Adjusted } \\
\mathrm{R}^{2}\end{array}$ & $\mathrm{~N}$ \\
\hline $\begin{array}{l}\text { 1. Satisfaction in the birth country: } \\
\text { from OLS country dummies }\end{array}$ & $0.325^{* * *}$ & $(0.034)$ & 0.236 & 12085 \\
$\begin{array}{l}\text { Satisfaction in the birth country: } \\
\text { from World Values Survey }\end{array}$ & $0.249^{* * *}$ & $(0.025)$ & 0.208 & 18072 \\
$\begin{array}{l}\text { More individual control } \\
\text { variables }\end{array}$ & $0.267^{* * *}$ & $(0.037)$ & 0.262 & 12085 \\
$\begin{array}{l}\text { 4. Residence country controls } \\
\text { 5. Birth country controls }\end{array}$ & $0.292^{* * *}$ & $(0.039)$ & 0.238 & 10652 \\
& $0.216^{* * *}$ & $(0.040)$ & 0.247 & 10576 \\
\hline
\end{tabular}

Dependent variable: Life satisfaction. Robust standard errors adjusted for clustering by birth country are in parentheses. All regressions include the same control variables as in Table 2. Dummies are included for missing regressors.

Row 1: Average life satisfaction in the birth country: coefficients on country dummies from OLS with standard individual control variables from Table 2.

Row 2: Average life satisfaction in the birth county: from World Values Survey data.

Row 3: additional controls to Table 2: religiousness, seven dummies for sociability, dummy for whether the respondent has anyone to discuss intimate and personal matters with, dummy for citizenship, and five dummies for the length of time the respondent has lived in the residence country.

Row 4: additional controls to Table 2: Gini index, log GDP, and residence country's inflation and unemployment rate.

Row 5: additional controls to Table 2: Gini index, log GDP, and birth country's inflation and unemployment rate.

$* \mathrm{p}<0.10, * * \mathrm{p}<0.05, * * * \mathrm{p}<0.01$

\subsection{Heterogeneity}

Immigrants are not uniform: some keep the culture of origin more alive, while others are more assimilated. If the effect of average life satisfaction in the birth country indeed captures the effect of transmitted norms, beliefs and mental attitudes, the estimated coefficient should be higher for immigrants who are more attached to the birth country's culture, or in other words, who are less assimilated to the residence country. In other words, if the estimated coefficient is higher for immigrants who are more attached to the birth country's culture, we have strong indirect supporting evidence to our interpretation that average life satisfaction of the birth country captures the effect of culture. 
We create eight variables, each of which is supposed to indicate if an immigrant is less assimilated to the residence country, or in other words, if an immigrant is more attached to the birth country's culture.

1. Church attendance: Rice and Steel (2004) argue that church attendance is a relevant factor in the transmission of subjective well-being. They find that churchgoing Americans tend to be more embedded in the social networks of individuals with the same ancestry. Thus, in the group of regular church attenders the correlation between the well-being of Americans of foreign origin and the well-being of their ancestral country is stronger than among individuals who attend church less frequently. We assume that church attendance might also be a relevant indicator for immigrants' ethnic-related social networks in Europe, thus we create a binary indicator variable, which equals one if an immigrant attends religious services at least once a week.

2. Length of living in the residence country: Immigrants who have lived in the residence country for a shorter time might be influenced more by the culture of the birth country. On the other hand, merely due to the time effect, immigrants who have lived in the residence country for a longer time have more opportunity to change their norms, preferences and behavior, and might more likely adopt the local culture. We create a binary indicator variable, which equals one if an immigrant has lived in the residence country for less than ten years.

3. The effect of socialization: Immigrants who moved to a new country as an adult have less malleable values and attitudes and are less affected by peer groups, thus they might be less assimilated. On the other hand, for immigrants who were relatively young when they migrated, school and peer groups might be a strong enhancing factor for assimilation. In addition, because of their younger age they are also able to assimilate better. We create a binary indicator variable, which equals one if an immigrant moved to the new country as an adult (after age 25).

4. Citizenship: Becoming citizen of the residence country is a sign of assimilation, or at least intention for assimilation. Citizens of the residence country might keep the culture of origin less alive. Our binary indicator variable for citizenship equals one if an immigrant is noncitizen of the residence country.

5. Linguistic minority: Immigrants who speak the language of the residence country are able to become more embedded in the culture of their new home. Immigrants who use their original language remain part of their original culture. We use a binary indicator variable to capture this difference, which equals one if an immigrant uses a non-official language on a regular basis at home 
6. Share of immigrants: In a country with a high share of immigrants, people might be pushed less toward assimilation, thus maintaining the birth country culture might be easier. We construct a variable that measures the share of immigrants in the residence country ${ }^{13}$ and transform it to a binary indicator variable, which equals one if the residence country has an immigrant population of over 10 percent (high share of immigrants).

7. Level of xenophobia: It is reasonable to assume that if xenophobia is high in a given country, immigrants' rational or expected behavior is assimilation; in such a country the assimilation process is faster. Conversely, in a country with a lower level of xenophobia, immigrants might remain proud of their culture, and might maintain their culture. In the first step, we calculate xenophobia among natives with a principal component of three questions measuring the level of dislike for and fear of immigrants ${ }^{14}$ in all ESS rounds. Then we take the average of the five rounds by residence country. We create a binary indicator variable, which equals one if the level of xenophobia is low (below the median) in the residence country.

8. Discrimination on nationality: It is assumed that immigrants who were discriminated based on their nationality are less assimilated to the residence country culture. They are more likely to be victims of discrimination because their "ethnic identity" is more apparent, because they retain more their cultural identity than more assimilated immigrants. Thus discrimination on one's nationality might be a proxy for less assimilation. We create a binary indicator variable, which equals one if an immigrant describes himself/herself as a member of a group that is discriminated based on their nationality in the residence country.

We run eight models with the same control variables as in our main model in Table 2. Every model includes the respective indicator variable and an interaction term between satisfaction in the birth country and the indicator variable (Table 4). We expect the coefficient on the interaction term to be positive, i.e. among immigrants more attached to the birth country's culture the effect of average satisfaction should be higher than among immigrants assimilated into the residence country culture.

In row 1 of Table 4, contrary to Rice and Steel (2004) finding in their American sample, there appears no evidence that church attendance helps transmitting the culture in Europe: the estimated coefficient on the interaction term between religious service attendance and birth

\footnotetext{
${ }^{13}$ The data on the share of foreign-born population come from OECD Factbook 2011. We use data for 2005 because for this year they were available for most of the countries.

${ }^{14}$ The three questions (0-10 scales) are the following: "Would you say it is generally bad or good for [country]'s economy that people come to live here from other countries?", "Would you say that [country]'s cultural life is generally undermined or enriched by people coming to live here from other countries?", "Is [country] made a worse or a better place to live by people coming to live here from other countries?"
} 
country satisfaction is almost zero. A possible explanation for this finding is that in Europe religious groups and church attendance are less connected to ethnic groups and to ancestry culture. It is possible that in the United States church attendance is a proper measure of social networks, but in Europe (ethnic-related) social networks might be more likely to be formed outside of churches, thus are less connected to religion. Other formal and informal institutions and factors assist in maintaining and transmitting the birth country culture.

Row 2 presents that the length of living in the residence country alters the effect of satisfaction in the birth country. Birth country satisfaction is a significant determinant of wellbeing among immigrants who have lived in the residence country for more than ten years. The coefficient on the interaction term is positive and significant at the 10 percent level. Among immigrants who have lived in the residence country for a shorter time average satisfaction of the birth country appears to have higher impact. At the same time, satisfaction of the birth country has a significant impact even on the satisfaction of immigrants who have lived in their country of residence for over ten years.

Row 3 controls for the effect of socialization. We can clearly see that the older the age at migration the higher the effect of the birth country's satisfaction: the coefficient on the interaction term with coming to the residence country after age 25 is 0.220 and significant at the 1 percent level. This means that satisfaction of the birth country has a stronger impact among individuals who were adults at the time of their immigration. But persons who immigrated as children or young adults also have a 10 percent level significant effect (0.124). In row 4 we can see that the effect of satisfaction in the birth country varies by citizenship. The estimated effect of average satisfaction is somewhat higher among immigrants who are not citizens of their residence country (the coefficient on the interaction term is 0.112 and significant at the 10 percent level).

Row 5 shows that the effect of satisfaction of the birth country moderated by linguistic minority. Immigrants who use a non-official language of the residence country on a regular basis have a significantly stronger effect than other immigrants: the estimated coefficient of birth country's satisfaction is more than double for them $(0.168+0.194=0.362$ vs. 0.168$)$.

Row 6 provides evidence that immigrants in residence countries with a high share of foreignborn population are affected stronger by average satisfaction. The estimated coefficient on the interaction term is 0.200 and significant at the 1 percent level. However, satisfaction of the birth country also has a significant effect in countries with a low share of immigrants (0.139). Row 7 presents that the coefficient on average satisfaction of the birth country is positive and significant (0.188) in countries with high levels of xenophobia, however, the effect is even 
higher in countries with low levels of xenophobia. The coefficient on the interaction term is 0.144 and significant at the 10 percent level.

In row 8 , we test the assumption that discrimination on nationality moderates the main effect. The results tend to support the assumption that among immigrants who describes themselves as members of a group that is discriminated based on their nationality the estimated coefficient is higher than immigrants who were not, although the difference is not statistically significant.

To sum up, our results confirm that the effect of average satisfaction in the birth country tends to be higher for immigrants more attached to their birth country's culture, which corroborates our interpretation that the coefficient on satisfaction in the birth country captures the effect of culture (intrinsic cultural disposition, values, beliefs, norms). However, the effect of average satisfaction in the birth country is also positive and significant in all models for immigrants presumed to be more assimilated to the residence country's culture. Although they adopt more likely the culture of the new country, the birth country's culture still seems to be strong enough to influence their satisfaction. Moreover, since this evidence supports the interpretation regarding the effect of culture, the results relax the concerns that selective migration might spuriously generate our result. 
Table 4: Effects of satisfaction in the birth country on subjective well-being, OLS

\begin{tabular}{|c|c|c|c|c|c|}
\hline & & $\mathrm{B}$ & $\begin{array}{l}\text { Robust } \\
\text { SE }\end{array}$ & $\begin{array}{l}\text { Adjusted } \\
\mathrm{R}^{2}\end{array}$ & $\mathrm{~N}$ \\
\hline \multirow[t]{2}{*}{1.} & Satisfaction in the birth country & $0.290^{* * *}$ & $(0.031)$ & 0.239 & 12085 \\
\hline & $\begin{array}{l}\text { Attends religious services at least once a } \\
\text { week } \times \text { Satisfaction in the birth country }\end{array}$ & -0.020 & $(0.057)$ & & \\
\hline \multirow[t]{2}{*}{2.} & Satisfaction in the birth country & $0.247^{* * * *}$ & $(0.034)$ & 0.238 & 12085 \\
\hline & $\begin{array}{l}\text { Has lived in the residence country less than } \\
10 \text { years } \times \text { Satisfaction in the birth country }\end{array}$ & $0.091^{*}$ & $(0.045)$ & & \\
\hline \multirow[t]{2}{*}{3.} & Satisfaction in the birth country & $0.124^{*}$ & $(0.071)$ & 0.238 & 12085 \\
\hline & $\begin{array}{l}\text { Came to the residence country after age } 25 \times \\
\text { Satisfaction in the birth country }\end{array}$ & $0.220^{* * *}$ & $(0.075)$ & & \\
\hline \multirow[t]{2}{*}{4.} & Satisfaction in the birth country & $0.231^{* * *}$ & $(0.038)$ & 0.238 & 12085 \\
\hline & $\begin{array}{l}\text { Non-citizen of the residence country } \times \\
\text { Satisfaction in the birth country }\end{array}$ & $0.112^{*}$ & $(0.066)$ & & \\
\hline \multirow[t]{2}{*}{5.} & Satisfaction in the birth country & $0.168^{* * * *}$ & $(0.032)$ & 0.240 & 12085 \\
\hline & $\begin{array}{l}\text { Uses a non-official language on a regular } \\
\text { basis at home } \times \text { Satisfaction in the birth } \\
\text { country }\end{array}$ & $0.194^{* * * *}$ & $(0.067)$ & & \\
\hline \multirow[t]{2}{*}{6.} & Satisfaction in the birth country & $0.139^{* * * *}$ & $(0.047)$ & 0.181 & 10071 \\
\hline & $\begin{array}{l}\text { Share of immigrants above } 10 \% \times \\
\text { Satisfaction in the birth country }\end{array}$ & $0.200^{* * * *}$ & $(0.049)$ & & \\
\hline \multirow[t]{2}{*}{7.} & Satisfaction in the birth country & $0.188^{* * * *}$ & $(0.062)$ & 0.238 & 12085 \\
\hline & $\begin{array}{l}\text { Low level of xenophobia in the residence } \\
\text { country } \times \text { Satisfaction in the birth country }\end{array}$ & $0.144^{*}$ & $(0.078)$ & & \\
\hline \multirow[t]{2}{*}{8.} & Satisfaction in the birth country & $0.269^{* * *}$ & $(0.030)$ & 0.239 & 12085 \\
\hline & $\begin{array}{l}\text { Discriminated based on his/her nationality } \times \\
\text { Satisfaction in the birth country }\end{array}$ & 0.052 & $(0.129)$ & & \\
\hline
\end{tabular}

Dependent variable: Life satisfaction. Robust standard errors adjusted for clustering by birth country are in parentheses. All regressions include the same control variables as in Table 2. Dummies are included for missing regressors.

$* \mathrm{p}<0.10, * * \mathrm{p}<0.05, * * * \mathrm{p}<0.01$

\subsection{Second-generation immigrants}

Finally, it is examined whether the effect of satisfaction in the country of origin (the effect of transmitted values, norms, and beliefs) lasts across generations. From the second wave of the ESS, we have data for the birth country of respondents' parents. We analyze a sample of individuals who were born in their residence country, and at least one of their parents was 
born in a different ESS country. This sample of second-generation immigrants consists of 10,172 observations. We calculate life satisfaction in the parental birth country as the mean of the average satisfactions in the two parents' birth countries. ${ }^{15}$

Row 1 in Table 5 presents the result. One unit increase in the satisfaction of the parental birth country is associated with an increase of 0.132 in the second-generation immigrant's satisfaction. The size of the estimated coefficient is about half of those among first-generation immigrants.

In line with other findings (Casey and Dustmann 2010), mothers appear to be more important in value transmission: average satisfaction in the mother's birth country has a stronger effect on satisfaction of second-generation immigrants than average satisfaction in the father's birth country (row 2-3). ${ }^{16}$

Row 4 includes respondents whose parents were born in a WVS country as well. Like in row 2 of Table 3, we calculate average satisfaction in the parental birth country from the WVS dataset, thus we can analyze not only individuals with parents from the 34 ESS countries, but we have 88 birth countries of mothers and 84 birth countries of fathers. The estimated coefficient on average satisfaction in the parental birth country is 0.187 and significant at the 1 percent level.

These results suggest that the effect of average satisfaction in the parental birth country (or, in other words, the effect of culture) is persistent for at least two generations. These results also provide additional evidence against the possibility that our result is driven by selective migration.

\footnotetext{
${ }^{15} 2851$ individuals' both parents emigrated from ESS countries, and 7321 individuals have a native parent and an immigrant parent. We calculate life satisfaction of the country of origin as the mean of the average satisfactions in the two parents' birth countries, because with the mean of the satisfactions of the two parental birth countries we capture correctly the potential influence of the immigrant parent's culture, but the direct effect of the native parent's birth country culture is captured by residence country dummies.

${ }^{16}$ In these specifications, we use a sample of native respondents with a mother from another ESS country (row 2 ), and a sample of native respondents with a father from another ESS country (row 3). Satisfaction in the parental birth country is calculated as average satisfaction in the mother's (row 2) or in the father's birth country (row 3). However, models with satisfaction in the parental birth country calculated like in row 1 of Table 5 (as the mean of the average satisfactions in the two parent's birth countries) yields similar coefficient magnitudes.
} 
Table 5: Effects of satisfaction in the parental birth country on subjective well-being of second-generation immigrants, OLS

\begin{tabular}{lcccc}
\hline & $\begin{array}{c}\text { Coefficient on } \\
\text { satisfaction in the } \\
\text { parental birth country }\end{array}$ & $\begin{array}{c}\text { Robust } \\
\text { SE }\end{array}$ & $\begin{array}{c}\text { Adjusted } \\
\mathrm{R}^{2}\end{array}$ & $\mathrm{~N}$ \\
\hline $\begin{array}{l}\text { Satisfaction in the parental } \\
\text { birth country }\end{array}$ & $0.132^{* * *}$ & $(0.046)$ & 0.272 & 10172 \\
$\begin{array}{l}\text { Satisfaction in the mother's } \\
\text { birth country }\end{array}$ & $0.148^{* * *}$ & $(0.051)$ & 0.264 & 6411 \\
$\begin{array}{l}\text { Satisfaction in the father's } \\
\text { birth country }\end{array}$ & $0.099^{* *}$ & $(0.046)$ & 0.267 & 6612 \\
$\begin{array}{l}\text { Satisfaction in the parental } \\
\text { birth country: from the World }\end{array}$ & $0.187^{* * *}$ & & & \\
$\quad$ Values Survey & & $(0.039)$ & 0.260 & 12712 \\
\hline
\end{tabular}

Dependent variable: Life satisfaction. Robust standard errors adjusted for clustering by parental birth country are in parentheses. All regressions include the same control variables as in Table 2. Dummies are included for missing regressors.

$* \mathrm{p}<0.10, * * \mathrm{p}<0.05, * * * \mathrm{p}<0.01$

\section{Conclusion}

The aim of this paper has been to examine the effect of culture on life satisfaction. Using a sample of immigrants, we have provided evidence that, controlling for relevant sociodemographic and economic characteristics, in any particular residence country immigrants from countries with high life satisfaction levels are more satisfied than immigrants from countries with low life satisfaction levels. Living in the same country, immigrants with the same economic and socio-demographic characteristics differ only in their cultural backgrounds. Thus, our finding indicates that culture (transmitted values, norms and beliefs) is a significant determinant of subjective well-being.

Our interpretation has been corroborated by the results that the effect of satisfaction in the birth country is stronger among immigrants more attached to their birth country's culture. Immigrants who have lived in their residence country for a shorter time, moved to their new country after the age of 25 , are non-citizens of their residence country, use a non-official language on a regular basis at home tend to be more affected by the birth country' satisfaction. In countries where the share of immigrant population is higher, where immigrants' rational or expected behavior is not assimilation, the effect of satisfaction in the birth country also appears to be stronger. This effect is robust to controlling for 
comprehensive individual variables and for economic and social characteristics of the birth and the residence country, and to the choice of the sample.

Culture is not the only, or even the primary factor that explains well-being, but it has a statistically significant and socially and economically meaningful effect. By using a sample of second-generation immigrants, we have also shown that this effect lasts across generations.

Although our results suggest that culture affects well-being, we need more research to specify what values, norms or beliefs can best explain the effect of culture. As we have seen earlier, some of them have been already studied: for example interpersonal trust (Helliwell and Wang 2011), post-materialism and materialism (Kasser and Ahuvia 2002), individualism and collectivism (Diener et al. 1999; Suh and Oishi 2002), optimism (Diener et al. 1999). But it is a task for future, methodologically well-founded research to determine which of these aspects of culture do influence well-being besides economic, institutional and social factors.

The most important implication of our findings that - beside extrinsic economic, social and institutional factors - subjective well-being is determined by intrinsic cultural factors, thus in explaining international differences in life satisfaction culture cannot be neglected: a sizeable part of these differences can be explained by the variation in norms, beliefs or mental attitudes.

Although our primary focus has been on using a sample of immigrants to identify the effects of culture, the findings also shed light on determinants of immigrants' well-being and on the transmission of cultural values in more general terms. Our result suggests that cultural heritage should be taken into account in designing policies pertaining to immigrants. Although discussing the details of the social and managerial implications for immigrants' well-being or for transmission of cultural values are beyond the scope of this paper, these analyses might be important, as international migration is one of the main challenges of our world today.

\section{Acknowledgements}

We thank Gábor Kézdi, Matild Sági and Endre Sik for their comments, as well as participants in the HAS Institute for Sociology Young Researchers' Conference (Budapest, December 2011), and the 11th ISQOLS Conference (Venice, November 2012). We also thank the useful comments of two anonymous reviewers. Remaining errors are solely ours. 


\section{References}

Alesina, A., Di Tella, R., \& MacCulloch, R. (2004). Inequality and happiness: are Europeans and Americans different? Journal of Public Economics, 88(9-10), 2009-2042.

Alesina, A., \& Giuliano, P. (2010). The power of the family. Journal of Economic Growth, $15(2), 93-125$.

Algan, Y., \& Cahuc, P. (2010). Inherited Trust and Growth. American Economic Review, 100(5), 2060-2092.

Askitas, N., \& Zimmermann, K. F. (2011). Health and Well-Being in the Crisis. IZA Discussion Paper, No. 5601.

Blau, F. D., Kahn, L. M., Liu, A. Y.-H., \& Papps, K. L. (2013). The transmission of women's fertility, human capital, and work orientation across immigrant generations. Journal of Population Economics, 26(2), 405-435.

Blau, F. D., Kahn, L. M., \& Papps, K. L. (2011). Gender, Source Country Characteristics, and Labor Market Assimilation among Immigrants. Review of Economics and Statistics, 93(1), $43-58$.

Carroll, C. D., Rhee, B.-K., \& Rhee, C. (1994). Are There Cultural Effects on Saving? Some Cross-Sectional Evidence. The Quarterly Journal of Economics, 109(3), 685-699.

Casey, T., \& Dustmann, C. (2010). Immigrants' Identity, Economic Outcomes and the Transmission of Identity across Generations. Economic Journal, 120(542), F31-F51.

Deaton, A. (2008). Income, Health, and Well-Being around the World: Evidence from the Gallup World Poll. Journal of Economic Perspectives, 22(2), 53-72.

Deaton, A. (2012). The financial crisis and the well-being of Americans: 2011 OEP Hicks Lecture. Oxford Economic Papers, 64(1), 1-26.

Di Tella, R., MacCulloch, R. J., \& Oswald, A. J. (2003). The Macroeconomics of Happiness. Review of Economics and Statistics, 85(4), 809-827.

Diener, E. (Ed.). (2009). Culture and Well-Being: The Collected Works of Ed Diener. New York: Springer.

Diener, E., Diener, M., \& Diener, C. (1995). Factors Predicting the Subjective Well-Being of Nations. Journal of Personality and Social Psychology, 69(5), 851-864.

Diener, E., Inglehart, R., \& Tay, L. (2013). Theory and Validity of Life Satisfaction Scales. Social Indicators Research, 112(3), 497-527.

Diener, E., \& Suh, E. M. (Eds.). (2000). Culture and Subjective Well-Being. Cambridge, MA: MIT Press.

Diener, E., Suh, E. M., Lucas, R. E., \& Smith, H. L. (1999). Subjective Well-Being: Three Decades of Progress. Psychological Bulletin, 125(2), 276-302. 
Dinesen, P. T. (2013). Where You Come From or Where You Live? Examining the Cultural and Institutional Explanation of Generalized Trust Using Migration as a Natural Experiment. European Sociological Review, 29(1), 114-128.

Dolan, P., Peasgood, T., \& White, M. (2008). Do we really know what makes us happy? A review of the economic literature on the factors associated with subjective well-being. Journal of Economic Psychology, 29(1), 94-122.

Fernández, R. (2011). Does Culture Matter? In J. Benhabib, A. Bisin, \& M. O. Jackson (Eds.), Handbook of Social Economics (Volume 1, pp. 481-510): North-Holland.

Fernández, R., \& Fogli, A. (2006). Fertility: The Role of Culture and Family Experience. Journal of the European Economic Association, 4(2-3), 552-561.

Fernández, R., \& Fogli, A. (2009). Culture: An Empirical Investigation of Beliefs, Work, and Fertility. American Economic Journal: Macroeconomics, 1(1), 146-177.

Frey, B. S. (2008). Happiness. A Revolution in Economics. Cambridge MA: MIT Press.

Frey, B. S., \& Stutzer, A. (2002). Happiness and Economics: How the economy and institutions affect well-being. Princeton and Oxford: Princeton University Press.

Grosfeld, I., \& Senik, C. (2010). The emerging aversion to inequality. Economics of Transition, 18(1), 1-26.

Guiso, L., Sapienza, P., \& Zingales, L. (2006). Does Culture Affect Economic Outcomes? Journal of Economic Perspectives, 20(2), 23-48.

Hajdu, T., \& Hajdu, G. (2014). Reduction of Income Inequality and Subjective Well-Being in Europe. Economics: The Open-Access, Open-Assessment E-Journal, 8(2014-35), 1-29.

Helliwell, J. F., \& Putnam, R. D. (2004). The social context of well-being. Philosophical Transactions of the Royal Society B, 359, 1435-1446.

Helliwell, J. F., \& Wang, S. (2011). Trust and Wellbeing. International Journal of Wellbeing, $1(1), 42-78$.

Hui, C. H., \& Triandis, H. C. (1989). Effects of Culture and Response Format on Extreme Response Style. Journal of Cross-Cultural Psychology, 20(3), 296-309.

Inglehart, R., \& Klingemann, H.-D. (2000). Genes, Culture, Democracy and Happiness. In E. Diener, \& E. M. Suh (Eds.), Culture and Subjective Well-Being (pp. 165-183). Cambridge, MA: MIT Press.

Kasser, T., \& Ahuvia, A. (2002). Materialistic values and well-being in business students. European Journal of Social Psychology, 32, 137-146.

Kasser, T., \& Ryan, R. M. (1993). A dark side of American dream: Correlates of financial success as a central life aspiration. Journal of Personality and Social Psychology, 65(2), 410-422. 
Knoop, H. H., \& Delle Fave, A. (Eds.). (2013). Well-Being and Cultures. Perspectives from Positive Psychology. Dordrecht, NL: Springer.

Luttmer, E. F. P., \& Singhal, M. (2011). Culture, Context, and the Taste for Redistribution. American Economic Journal: Economic Policy, 3(1), 157-179.

Lykken, D., \& Tellegen, A. (1996). Happiness Is a Stochastic Phenomenon. Psychological Science, 7(3), 186-189.

OECD (2013). OECD Guidelines on Measuring Subjective Well-being: OECD Publishing.

Oishi, S. (2010). Culture and Well-Being: Conceptual and Methodological Issues. In E. Diener, J. F. Helliwell, \& D. Kahneman (Eds.), International Differences in Well-Being (pp. 34-69). New York: Oxford University Press.

Otrachshenko, V., \& Popova, O. (2014). Life (dis)satisfaction and the intention to migrate: Evidence from Central and Eastern Europe. Journal of Socio-Economics, 48, 40-49.

Rice, T. W., \& Steele, B. J. (2004). Subjective Well-Being and Culture Across Time and Space. Journal of Cross-Cultural Psychology, 35(6), 633-647.

Senik, C. (2014). The French unhappiness puzzle: The cultural dimension of happiness. Journal of Economic Behavior \& Organization, 106, 379-401.

Stevenson, B., \& Wolfers, J. (2013). Subjective Well-Being and Income: Is There Any Evidence of Satiation? American Economic Review, 103(3), 598-604.

Suh, E. M., \& Koo, J. (2008). Comparing Subjective Well-Being across Cultures and Nations. The "What" and "Why" Questions. In M. Eid, \& R. J. Larsen (Eds.), The Science of Subjective Well-Being (pp. 414-427). New York: The Guilford Press.

Suh, E. M., \& Oishi, S. (2002). Subjective Well-Being Across Cultures. Online Readings in Psychology and Culture, Unit 10. http://scholarworks.gvsu.edu/orpc/vol10/iss1/1. Accessed 24/11/2011

van de Vijver, F. J. R., \& Poortinga, Y. H. (1997). Towards an Integrated Analysis of Bias in Cross-Cultural Assessment. European Journal of Psychological Assessment, 13(1), 29-37.

Veenhoven, R. (1993). Happiness in nations: subjective appreciation of life in 56 nations, 1946-1992: Erasmus University of Rotterdam, Department of Social Sciences, RISBO, Center for Socio-Cultural Transformation.

Veenhoven, R. (1994). Is happiness a trait? Social Indicators Research, 32(2), 101-160.

Veenhoven, R. (1996). Developments in satisfaction-research. Social Indicators Research, $37(1), 1-46$.

Wolfers, J. (2003). Is Business Cycle Volatility Costly? Evidence from Surveys of Subjective Well-Being. International Finance, 6(1), 1-26. 


\section{Appendix}

Table A1: Summary statistics

\begin{tabular}{|c|c|c|c|c|c|}
\hline Variable & Mean & S.D. & Min & Max & $\mathrm{N}$ \\
\hline Life satisfaction & 6.674 & 2.435 & 0 & 10 & 12085 \\
\hline Satisfaction in the birth country & 6.314 & 0.911 & 4.50 & 8.50 & 12085 \\
\hline Age & 49.775 & 17.808 & 15 & 99 & 12085 \\
\hline Female & 0.572 & 0.495 & 0 & 1 & 12085 \\
\hline $\begin{array}{l}\text { Education: ISCED 5-6, tertiary education } \\
\text { completed }\end{array}$ & 0.327 & 0.469 & 0 & 1 & 11977 \\
\hline Married or living with a partner & 0.569 & 0.495 & 0 & 1 & 11965 \\
\hline Paid work & 0.485 & 0.500 & 0 & 1 & 11990 \\
\hline Education & 0.049 & 0.217 & 0 & 1 & 11990 \\
\hline Unemployed, looking for a job & 0.045 & 0.208 & 0 & 1 & 11990 \\
\hline Unemployed, not looking for a job & 0.018 & 0.134 & 0 & 1 & 11990 \\
\hline Retired & 0.260 & 0.439 & 0 & 1 & 11990 \\
\hline Housework & 0.102 & 0.303 & 0 & 1 & 11990 \\
\hline Other main activity & 0.039 & 0.195 & 0 & 1 & 11990 \\
\hline City/town & 0.733 & 0.443 & 0 & 1 & 12023 \\
\hline Activity limitation & 0.279 & 0.448 & 0 & 1 & 11968 \\
\hline Log household's total net income & 7.113 & 1.301 & 2.33 & 9.95 & 9640 \\
\hline Relative income & 0.958 & 0.959 & 0.014 & 27.81 & 9640 \\
\hline Household size & 2.629 & 1.335 & 1 & 6 & 12076 \\
\hline Religiousness & 4.795 & 3.048 & 0 & 10 & 11948 \\
\hline $\begin{array}{l}\text { Never meets socially friends, relatives or } \\
\text { work colleagues }\end{array}$ & 0.024 & 0.153 & 0 & 1 & 12046 \\
\hline $\begin{array}{l}\text { Meets socially friends, relatives or work } \\
\text { colleagues less than once a month }\end{array}$ & 0.094 & 0.291 & 0 & 1 & 12046 \\
\hline $\begin{array}{l}\text { Meets socially friends, relatives or work } \\
\text { colleagues once a month }\end{array}$ & 0.105 & 0.307 & 0 & 1 & 12046 \\
\hline $\begin{array}{l}\text { Meets socially friends, relatives or work } \\
\text { colleagues several times a month }\end{array}$ & 0.183 & 0.387 & 0 & 1 & 12046 \\
\hline $\begin{array}{l}\text { Meets socially friends, relatives or work } \\
\text { colleagues once a week }\end{array}$ & 0.198 & 0.399 & 0 & 1 & 12046 \\
\hline $\begin{array}{l}\text { Meets socially friends, relatives or work } \\
\text { colleagues several times a week }\end{array}$ & 0.256 & 0.436 & 0 & 1 & 12046 \\
\hline $\begin{array}{l}\text { Meets socially friends, relatives or work } \\
\text { colleagues every day }\end{array}$ & 0.140 & 0.347 & 0 & 1 & 12046 \\
\hline Non-citizen of the residence country & 0.425 & 0.494 & 0 & 1 & 12065 \\
\hline
\end{tabular}




\begin{tabular}{|c|c|c|c|c|c|}
\hline Variable & Mean & S.D. & Min & Max & $\mathrm{N}$ \\
\hline $\begin{array}{l}\text { Has lived in the residence country for } 0-1 \\
\text { year }\end{array}$ & 0.013 & 0.112 & 0 & 1 & 11914 \\
\hline $\begin{array}{l}\text { Has lived in the residence country for 1-5 } \\
\text { years }\end{array}$ & 0.100 & 0.300 & 0 & 1 & 11914 \\
\hline $\begin{array}{l}\text { Has lived in the residence country for 6-10 } \\
\text { years }\end{array}$ & 0.098 & 0.298 & 0 & 1 & 11914 \\
\hline $\begin{array}{l}\text { Has lived in the residence country for 10-20 } \\
\text { years }\end{array}$ & 0.190 & 0.393 & 0 & 1 & 11914 \\
\hline $\begin{array}{l}\text { Has lived in the residence country for over } \\
20 \text { years }\end{array}$ & 0.599 & 0.490 & 0 & 1 & 11914 \\
\hline $\begin{array}{l}\text { Has someone to discuss intimate and } \\
\text { personal matters with }\end{array}$ & 0.877 & 0.329 & 0 & 1 & 11945 \\
\hline Discriminated based on his/her nationality & 0.057 & 0.232 & 0 & 1 & 12007 \\
\hline $\begin{array}{l}\text { Attends religious services at least once a } \\
\text { week }\end{array}$ & 0.132 & 0.338 & 0 & 1 & 12017 \\
\hline $\begin{array}{l}\text { Uses a non-official language on a regular } \\
\text { basis at home }\end{array}$ & 0.422 & 0.494 & 0 & 1 & 12044 \\
\hline Came to the residence country after age 25 & 0.743 & 0.437 & 0 & 1 & 11914 \\
\hline Share of immigrants above $10 \%$ & 0.818 & 0.386 & 0 & 1 & 10071 \\
\hline $\begin{array}{l}\text { Xenophobia in the residence country below } \\
\text { median }\end{array}$ & 0.563 & 0.496 & 0 & 1 & 12085 \\
\hline Log GDP in residence country & 9.711 & 0.971 & 6.87 & 10.82 & 12085 \\
\hline Gini index in residence country & 29.229 & 4.248 & 21.92 & 45.24 & 10652 \\
\hline Unemployment rate in residence country & 7.137 & 3.346 & 2.60 & 19.90 & 11044 \\
\hline Inflation rate in residence country & 3.378 & 3.146 & -4.48 & 15.89 & 12085 \\
\hline Log GDP in birth country & 8.994 & 1.079 & 6.61 & 10.91 & 12085 \\
\hline Gini index in birth country & 33.271 & 6.708 & 21.92 & 45.24 & 10576 \\
\hline Unemployment rate in birth country & 8.266 & 3.010 & 2.60 & 20.10 & 10937 \\
\hline Inflation rate in birth country & 5.851 & 6.058 & -1.09 & 44.96 & 12085 \\
\hline ESS Wave 1 & 0.180 & 0.384 & 0 & 1 & 12085 \\
\hline ESS Wave 2 & 0.208 & 0.406 & 0 & 1 & 12085 \\
\hline ESS Wave 3 & 0.174 & 0.379 & 0 & 1 & 12085 \\
\hline ESS Wave 4 & 0.232 & 0.422 & 0 & 1 & 12085 \\
\hline ESS Wave 5 & 0.206 & 0.405 & 0 & 1 & 12085 \\
\hline
\end{tabular}


Table A2: Effects of satisfaction in the birth country on subjective well-being, OLS

\begin{tabular}{|c|c|c|c|c|c|}
\hline & & $\begin{array}{l}\text { Coefficient on } \\
\text { satisfaction in } \\
\text { the birth country }\end{array}$ & $\begin{array}{c}\text { Robust } \\
\text { SE }\end{array}$ & $\begin{array}{l}\text { Adjusted } \\
\mathrm{R}^{2}\end{array}$ & $\mathrm{~N}$ \\
\hline 1. & $\begin{array}{l}\text { Without post-communist birth } \\
\text { countries }\end{array}$ & $0.357^{* * *}$ & $(0.069)$ & 0.146 & 6202 \\
\hline 2. & $\begin{array}{l}\text { Omitting } 5 \text { birth countries with } \\
\text { the lowest satisfaction }\end{array}$ & $0.335^{* * *}$ & $(0.053)$ & 0.172 & 8392 \\
\hline 3. & $\begin{array}{l}\text { Omitting } 5 \text { birth countries with } \\
\text { the highest satisfaction }\end{array}$ & $0.280^{* * * *}$ & $(0.034)$ & 0.234 & 11602 \\
\hline 4. & ESS 1. wave & $0.356^{* * *}$ & $(0.059)$ & 0.154 & 2170 \\
\hline 5. & ESS 2. wave & $0.303^{* * *}$ & $(0.066)$ & 0.287 & 2516 \\
\hline 6. & ESS 3. wave & $0.294^{* * *}$ & $(0.074)$ & 0.295 & 2098 \\
\hline 7. & ESS 4. wave & $0.245^{* * *}$ & $(0.060)$ & 0.251 & 2809 \\
\hline 8. & ESS 5. wave & $0.206^{* * *}$ & $(0.072)$ & 0.209 & 2492 \\
\hline 9. & $\begin{array}{l}\text { Only countries participating at } \\
\text { least in } 4 \text { waves }\end{array}$ & $0.265^{* * *}$ & $(0.035)$ & 0.256 & 8942 \\
\hline 10. & $\begin{array}{l}\text { Only residence and birth countries } \\
\text { with at least } 100 \text { observations } \\
\text { each }\end{array}$ & $0.290^{* * *}$ & $(0.032)$ & 0.234 & 11402 \\
\hline 11. & $\begin{array}{l}\text { Only residence countries with } \\
\text { immigrants from at least } 10 \\
\text { different countries }\end{array}$ & $0.305^{* * *}$ & $(0.032)$ & 0.233 & 11202 \\
\hline 12. & Ordered logit & $0.243^{* * *}$ & $(0.027)$ & $0.061^{\mathrm{a}}$ & 12085 \\
\hline 13. & Ordered probit & $0.138^{* * *}$ & $(0.015)$ & $0.058^{\mathrm{a}}$ & 12085 \\
\hline 14. & Weighted by design weights & $0.278^{* * *}$ & $(0.031)$ & 0.236 & 12085 \\
\hline
\end{tabular}

Dependent variable: Life satisfaction. Robust standard errors adjusted for clustering by birth country are in parentheses. Dummies are included for missing regressors. Rows 1-14: Regressions include individual controls as in Table 2.

${ }^{a}$ Pseudo $\mathrm{R}^{2}$

$* \mathrm{p}<0.10, * * \mathrm{p}<0.05, * * * \mathrm{p}<0.01$ 